\title{
Double-blind placebo-controlled study of loperamide (Imodium) in chronic diarrhoea caused by ileocolic disease or resection
}

\author{
P. MAINGUET AND R. FIASSE
}

From the Department of Gastro-enterology and the Department of Medicine, Cliniques Universitaires St. Pierre, B-3000 Louvain, Belgium

SUMMARY Loperamide ( $R$ 18 553) was compared with placebo in a double-blind crossover study of 21 patients with chronic diarrhoea caused by ileocolic disease or resection. Eighteen patients completed the trial. At a median daily dose of $6 \mathrm{mg}$ the new antidiarrhoeal preparation was found to be superior to placebo in controlling chronic diarrhoea. The frequency and weight of stools significantly decreased, the stools became more solid, and carmine transit time was prolonged during loperamide therapy. Loperamide was consistently preferred to placebo by the patients. Gastrointestinal sideeffects were few and comparable during both treatment periods.

Loperamide ( $R$ 18 553) is a new antidiarrhoeal drug, chemically related to haloperidol and diphenoxylate, which at low doses prolongs intestinal transit time and effectively controls castor oil-induced diarrhoea in animals (Stockbroekx et al., 1973; Niemegeers et al., 1974a; 1974b). On the basis of the results of in vitro studies, loperamide's antiperistaltic activity has been attributed to a direct effect on the muscles of the intestinal wall, which is mediated by local interaction with both intramural ganglia and acetylcholine release at the nerve endings (Van Nueten et al., 1974).

Animal pharmacological data demonstrate that loperamide is more potent, more specific, and longeracting that the commonly used antidiarrhoeal, diphenoxylate (Niemegeers et al., 1974a; 1974b), and has a wide safety margin on oral administration (Niemegeers et al., 1974a). Prolonged administration to rats, rabbits, and dogs is welltolerated, with no apparent toxicity, interference with reproductive processes, or teratogenicity (Marsboom et al., 1974). In human volunteers (Schuermans et al., 1974), loperamide has been shown to be about three times more potent than diphenoxylate and 50 times more potent than codeine in inducing constipation; it is also significantly longer-acting than diphenoxylate (Schuermans et al., 1974). There is complete dissociation of gastro-

Received for publication 20 December 1976 intestinal and CNS effects with this preparation (Niemegeers et al., 1974a; 1974b; Schuermans et al., 1974), and, therefore, loperamide should lack any addictive properties.

Previous clinical trials showed that loperamide induces symptomatic relief in both acute and chronic diarrhoea (De Coster et al., 1972; Demeulenaere et al., 1974; Dom et al., 1974; Verhaegen et al., 1974; Amery et al., 1975; Pelemans and VanTrappen, 1976), but the effect of this treatment on the intestinal transit time has not yet been evaluated.

The aim of this study was to evaluate the effects of loperamide by a double-blind controlled study in patients suffering from severe chronic diarrhoea showing no tendency to spontaneous remission, and to verify its anticipated effect on the intestinal transit time.

\section{Methods}

We selected 21 out-patients (11 females and 10 males) ranging in age from 21 to 63 years (median age 43 years) for this study. The aetiology of the diarrhoea in these patients was extensive ileocolic lesions or resections, mostly because of Crohn's disease.

The characteristics of the individual patients, including aetiology of diarrhoea, data pertinent to the resection, and extent of the current illness (based on radiographic evaluation), are shown in Table 1. 
Table 1 Characteristics of patients

\begin{tabular}{|c|c|c|c|c|}
\hline $\begin{array}{l}\text { Patient's } \\
\text { initials }\end{array}$ & Sex, age $(y r)$ & Aetiology of chronic diarrhoea & $\begin{array}{l}\text { Length and type of resections } \\
\text { (yr of surgery) }\end{array}$ & $\begin{array}{l}\text { Extent of present illness } \\
\text { ( } x \text {-ray evaluation })\end{array}$ \\
\hline DE & F 41 & $\begin{array}{l}\text { Crohn's disease } \\
\text { (resection and recurrence) }\end{array}$ & $\begin{array}{l}40 \mathrm{~cm} \text { terminal ileum }+ \\
\text { ascending colon }+1 / 2 \text { transverse } \\
\text { colon }(1960) .25 \mathrm{~cm} \text { ileum } \\
+10 \mathrm{~cm} \text { transverse colon }(1965)\end{array}$ & $30 \mathrm{~cm}$ ileum \\
\hline DM & F 24 & $\begin{array}{l}\text { Crohn's disease } \\
\text { (resection) }\end{array}$ & $\begin{array}{l}50 \mathrm{~cm} \text { small intestine }+ \text { caecum } \\
+1 / 2 \text { ascending colon }(1970)\end{array}$ & No relapse \\
\hline VC & M 43 & Crohn's disease & & $30 \mathrm{~cm}$ ileum + caecum \\
\hline VE & F 52 & Recurrence of Crohn's disease & $\begin{array}{l}65 \mathrm{~cm} \text { small intestine }+ \text { caecum } \\
(1960)\end{array}$ & $25 \mathrm{~cm}$ ileum \\
\hline GI & F 45 & Recurrence of Crohn's disease & $\begin{array}{l}80 \mathrm{~cm} \text { small intestine }+15 \mathrm{~cm} \\
\text { caecum (1966) }\end{array}$ & $15 \mathrm{~cm}$ ileum \\
\hline DM & F 32 & Crohn's disease & & $\begin{array}{l}40 \mathrm{~cm}+1 / 2 \text { colon ascendens }+ \\
\text { transverse }\end{array}$ \\
\hline $\mathrm{CV}$ & F 51 & Resection of Crohn's disease & $\begin{array}{l}120 \mathrm{~cm} \text { terminal ileum }+ \\
\text { caecum (1961) }\end{array}$ & No relapse \\
\hline $\mathbf{C A}$ & M 55 & Recurrence of Crohn's disease & $\begin{array}{l}70 \mathrm{~cm} \text { terminal ileum }+1 / 2 \\
\text { ascending colon }(1970)\end{array}$ & $20 \mathrm{~cm}$ ileum \\
\hline GG & F 55 & Resection of radiation ileitis & Ileum (1970) & No relapse \\
\hline $\mathbf{L M}$ & M 21 & Crohn's disease & & $\begin{array}{l}50 \mathrm{~cm} \text { ileum }+ \text { colon. Right } \\
\text { and } 1 / 2 \text { transverse }\end{array}$ \\
\hline $\mathbf{C V}$ & M 29 & Recurrence of Crohn's disease & $\begin{array}{l}30 \mathrm{~cm} \text { terminal ileum }+ \\
\text { caecum (1969) }\end{array}$ & $15 \mathrm{~cm}$ ileum \\
\hline $\mathbf{B M}$ & M 41 & Resection of Crohn's disease & $\begin{array}{l}1 / 2 \text { ascending colon }+1 / 2 \\
\text { transverse colon }+40 \mathrm{~cm} \text { terminal } \\
\text { ileum }+60 \mathrm{~cm} \text { small intestine } \\
(1952,1972)\end{array}$ & $20 \mathrm{~cm}$ ileum \\
\hline MI & $\mathbf{M}^{*}$ & $\begin{array}{l}\text { Resection of lipophagia } \\
\text { granulomatosis }\end{array}$ & $\begin{array}{l}30 \mathrm{~cm} \text { terminal ileum }+ \text { caecum } \\
(1970)\end{array}$ & No abnormalities \\
\hline AR & M 47 & Recurrence of Crohn's disease & $\begin{array}{l}30 \mathrm{~cm} \text { ileum }+ \text { part of caecum } \\
(1956)\end{array}$ & $7 \mathrm{~cm}$ ileum \\
\hline GG & M 43 & Recurrence of Crohn's disease & $\begin{array}{l}40 \mathrm{~cm} \text { ileum }+ \text { ascending colon } \\
+1 / 3 \text { transverse colon (1967) }\end{array}$ & $20 \mathrm{~cm}$ ileum \\
\hline $\mathbf{R C}$ & F 57 & Resection of mesenteric infarction & $\begin{array}{l}\text { Distal jejunum }+ \text { ileum }+ \\
\text { ascending colon }+1 / 2 \\
\text { transverse colon }(1969)\end{array}$ & No abnormalities \\
\hline $\mathbf{L J}$ & M 63 & Resection of mesenteric infarction & $\begin{array}{l}\text { Distal jejunum }+ \text { ileum }+ \\
\text { ascending and } 1 / 2 \text { transverse } \\
\text { colon (1969) }\end{array}$ & No abnormalities \\
\hline MJ & F 37 & Resection of Crohn's disease & $\begin{array}{l}180 \mathrm{~cm} \text { ileum + colectomy } \\
(1970)\end{array}$ & No relapse \\
\hline SM & F 60 & Recurrence of Crohn's disease & $60 \mathrm{~cm}$ ileum (1969) & $50 \mathrm{~cm}$ ileum \\
\hline DA & M 28 & Resection of Crohn's disease & $\begin{array}{l}30 \mathrm{~cm} \text { ileum }+ \text { ascending colon } \\
+ \text { transverse colon }(1962,1965 \\
1966)\end{array}$ & $10 \mathrm{~cm}$ ileum \\
\hline IL & $\mathbf{F}^{*}$ & Resection of intestinal obstruction & $\begin{array}{l}120 \mathrm{~cm} \text { ileum + ileostomy } \\
(1972)\end{array}$ & No abnormalities \\
\hline
\end{tabular}

* Age unknown.

The trial ran from December 1972 to February 1974.

Additional dosage adjustments were made by the patient, increasing or decreasing medication according to his needs until the individual optimum level was achieved. The maximum dose permitted was six

EXPERIMENTAL DESIGN

Loperamide was compared with placebo in a doubleblind crossover plan. Accordingly, each patient was randomly assigned to treatment with loperamide or placebo and then switched to the alternate medication in the subsequent treatment period.

At the beginning of each treatment period the patient was supplied with a quantity of capsules, containing $2 \mathrm{mg}$ loperamide or placebo, sufficient to meet the maximum need during the proposed fourweek trial. The initial daily dose was two capsules. capsules per day. Carmine red $(500 \mathrm{mg})$ was administered for measuring the transit time-that is, the period from intake of drug till the first occurrence of reddish stools.

The study was conducted on an ambulatory basis thus avoiding the effect of bed-rest on gastrointestinal transit time; normal occupations and specific diets were also followed. All opiates, diphenoxylate, antispasmodics, and coating agents were withdrawn, but other previously prescribed 
drugs (chiefly sulphasalazine) were continued throughout the trial, at the same dose.

Patients were instructed to return for evaluation after approximately four weeks or earlier if treatment seemed inadequate. Each patient had been instructed to complete preprinted record forms on which he was asked to record the number of bowel movements daily, the consistency of these motions (liquid, loose, or formed), the daily weight of the stools (at least three consecutive days each week), the carmine transit time (interval between intake and first appearance of carmine red) and any adverse reactions. To that end, a container for measuring the daily faecal output and capsules containing $500 \mathrm{mg}$ officinal carmine red had been given to the patients together with instructions for their use. Each treatment period concluded with a clinical and laboratory examination.

The investigators completed a follow-up record form for each patient, summarising the data recorded by the patients during each treatment period, calculating their mean daily faecal output from the data of three consecutive days, and indicating the patient's preference for either treatment period, on the basis of the available data.

Statistical analyses were performed on individual median values using the Wilcoxon matched-pairs signed-ranks test (Siegel, 1956). This approach was deemed the most suitable for the evaluation of paired observations with unequal distribution of the data. Patients' preferences and adverse experiences were analysed by the binomial test.

\section{Results}

Eighteen of the original 21 patients completed the trial. Three were withdrawn because of failure to co-operate. Five patients took part twice in the study; only data from the first participation were evaluated, although those from the other participation proved similar.
No sequential effect was demonstrated between treatment periods for any parameter considered $(P>0.05)$.

Table 2 presents the results of the trial.

The number of evaluated pairs (maximum of 18) is indicated because for a few patients complete information was not available for some parameters in both treatment periods. Whereas the median duration of all loperamide treatment periods was 37 days (several patients delayed the fourth-week evaluation as they were satisfied with the treatment and had not yet run out of their supply), it was only 16.5 days with placebo. This difference was statistically significant $(P<0.001)$.

The frequency, consistency, and weight of the stools were uniformly superior during loperamide treatment as compared with the placebo treatment ( $P<0.001$ for all parameters). Fewer loperamide than placebo capsules (median of three versus $4 \cdot 5$ ) were consumed each day $(P<0.001)$. The median dose of loperamide was therefore $6 \mathrm{mg}$. Carmine transit time was measured after a median duration of treatment of nine days with placebo and 21 days in the loperamide group; it proved significantly longer during administration of loperamide $(P<0.001)$. Every patient's global appreciation of all parameters favoured the loperamide treatment period $(P<0.001)$.

Eight patients reported side-effects with loperamide (nausea, vomiting, abdominal pain, distension) and an equal number of subjects experienced the same complaints during the placebo period (Table 3). There was no significant difference between the two periods $(P>0.05)$.

\section{Discussion}

The efficacy of loperamide in chronic diarrhoea has been demonstrated by previous studies (De Coster et al., 1972; Demeulenaere et al., 1974; Verhaegen et al., 1974).

Table 2 Comparison of loperamide versus placebo

\begin{tabular}{|c|c|c|c|c|}
\hline \multirow[t]{2}{*}{ Parameter } & \multirow{2}{*}{$\begin{array}{l}\text { No. of patients with } \\
\text { complete information } \\
\text { for both periods } \\
(\max .18)\end{array}$} & \multicolumn{3}{|c|}{ Placebo versus loperamide } \\
\hline & & \multicolumn{2}{|c|}{ Median values } & $\mathbf{P}^{*}$ \\
\hline \multirow[t]{2}{*}{$\begin{array}{l}\text { Duration of periods (days) } \\
\text { Median daily no. capsules taken } \\
\text { Median daily no. liquid motions } \\
\text { Median daily no. unformed motions (liquid + loose) } \\
\text { Median weight of stools (in grams) } \\
\text { Median carmine transit time (h) } 1 \text { day }\end{array}$} & $\begin{array}{l}18 \\
18 \\
16 \\
16 \\
13 \\
14\end{array}$ & $\begin{array}{c}16 \cdot 5 \\
4 \cdot 5 \\
4 \\
4 \cdot 5 \\
800 \\
2 \cdot 25\end{array}$ & $\begin{array}{c}37 \\
3 \\
0 \\
1 \cdot 5 \\
480 \\
4 \cdot 6\end{array}$ & $\begin{array}{l}<0.001 \\
<0.001 \\
<0.001 \\
<0.001 \\
<0.001 \\
<0.001\end{array}$ \\
\hline & Placebo & & Loperamide & $\mathbf{P t}$ \\
\hline Patients' preferences (18 patients) & 0 & & 18 & $<0.001$ \\
\hline
\end{tabular}

*Wilcoxon matched-pairs signed-ranks test (one-tailed probability).

+Binomial test (one-tailed probability). 
Table 3 Adverse experiences reported

\begin{tabular}{llll}
\hline Adverse experiences & \multicolumn{2}{l}{ Placebo versus loperamide } \\
\cline { 2 - 3 } & \multicolumn{2}{l}{ No. patients complaining } & $\mathbf{P}^{*}$ \\
\cline { 2 - 3 } & Placebo alone & $\begin{array}{l}\text { Loperamide } \\
\text { alone }\end{array}$ \\
\hline Nausea & 1 & 3 & NS \\
Vomiting & 1 & 1 & NS \\
Abdominal pain & 4 & 2 & NS \\
Meteorism & 2 & 2 & NS \\
\hline
\end{tabular}

*Binomial test (one-tailed probability).

NS: not significant $(P>0.05)$.

The entire study group described here suffered from severe chronic diarrhoea caused exclusively by organic disorders, without any tendency to spontaneous remission. In spite of the small sample size (which was limited by stringent selection criteria), alleviation of diarrhoea was more effective with loperamide than with placebo. For all parameters of antidiarrhoeal efficacy evaluated (duration of treatment period, number of capsules taken, frequency, consistency and weight of stools, carmine transit time) a median dose of $6 \mathrm{mg}$ loperamide proved significantly better than placebo. Of the three objective criteria considered-that is, daily number of stools, daily weight of stools, carmine transit time-transit time is obviously the least sensitive indicator of the drug's effectiveness as only marked changes will reveal significant differences. It should be noted that in all but one case, the improvements observed in these three parameters appeared concurrently.

No clearly drug-related side-effects occurred. It is likely that the adverse reactions reported are all associated with the disease state inasmuch as their incidence did not differ with either treatment regimen.

The shortening of transit time in patients with ileal resection or non-operated regional enteritis as compared with that of controls has been documented by Meihoff and Kern (1968) using another dye method. Shortened transit time may also be an important feature of regional enteritis, however (Kalser et al., 1960; Wright and Tilson, 1971). The majority of our patients (15 of 18) had undergone intestinal resections. One of the most important causes of diarrhoea in such patients is the reduction in transit time. This reduction is related primarily to the extent of the resection and to possible ablation of the ileocaecal valve; these, in turn, probably result in bile acid and fatty acid catharsis, further shortening the transit time. In our group of patients, the effect of loperamide is probably caused by this action on the transit time, previously demonstrated as significant in both animal and human subjects (Niemegeers et al., 1974b; Schuermans et al., 1974). As loperamide considerably prolonged transit time in this study, too, the drug should prove to be particularly useful in patients with intestinal resections or with extensive regional enteritis.

\section{References}

Amery, W., Duyck, F., Polak, J., and van den Bouwhuysen, G. (1975). A multicentre double-blind study in acute diarrhoea comparing loperamide ( $R$ 18553 ) with two common antidiarrhoeal agents and a placebo. Current Therapeutic Research, Clinical and Experimental, 17, 263-270.

De Coster, M., Kerremans, R., and Beckers, J. (1972). A comparative double-blind study of two antidiarrhoeals, difenoxine and loperamide. Tijdschrift voor Gastroenterologie, 15, 337-342.

Demeulenaere, L., Verbeke, S., Muls, M., and Reyntjens, A. (1974). Loperamide: an open multicentre trial and a double-blind cross-over comparison with placebo in patients with chronic diarrhoea. Current Therapeutic Research, Clinical and Experimental, 16, 32-39.

Dom, J., Leyman, R., Schuermans, V., and Brugmans, J. (1974). Loperamide ( $R$ 18 553), a novel type of antidiarrheal agent. Part 8. Clinical investigation. Use of a flexible dosage schedule in a double-blind comparison of loperamide with diphenoxylate in 614 patients suffering from acute diarrhea. Arzneimittel-Forschung, 24, 16601665.

Kalser, M. H., Roth, J. L. A., Tumen, H., and Johnson, T. A. (1960). Relation of small bowel resection to nutrition in man. Gastroenterology, 38, 605-615.

Marsboom, R., Hérin, V., Verstraeten, A., Vandesteene, R., and Fransen, J. (1974). Loperamide (R 18 553), a novel type of antidiarrheal agent. Part 4. Studies on subacute and chronic toxicity on reproductive processes in rats, dogs and rabbits. Arzneimittel-Forschung, 24, 1645-1649.

Meihoff, W. E., and Kern, F. (1968). Bile salt malabsorption in regional ileitis, ideal resection, and mannitol-induced diarrhea. Journal of Clinical Investigations, 47, 261-267.

Niemegeers, C. J. E., Lenaerts, F. M., and Janssen, P. A. J. (1974a). Loperamide ( $R$ 18 553), a novel type of antidiarrheal agent. Part 1. In vivo oral pharmacology and acute toxicity. Comparison with morphine, codeine, diphenoxylate and difenoxine. Arzneimittel-Forschung, 24, 1633-1636.

Niemegeers, C. J. E., Lenaerts, F. M., and Janssen, P. A. J. (1974b). Loperamide ( $R \quad 18553$ ), a novel type of antidiarrheal agent. Part 2. In vivo parenteral pharmacology and acute toxicity in mice. Comparison with morphine, codeine and diphenoxylate. Arzneimittel-Forschung, 24, 1636-1641.

Pelemans, W., and Van Trappen, G. (1976). Double-blind cross-over comparison of loperamide with diphenoxylate in a symptomatic treatment of chronic diarrhea. Gastroenterology, 70, 1030-1034.

Schuermans, V., Van Lommel, R., Dom, J., and Brugmans, J. (1974). Loperamide ( $R$ 18 553), a novel type of antidiarrheal agent. Part 6. Clinical pharmacology. Placebocontrolled comparison of the constipating activity and safety of loperamide, diphenoxylate and codeine in normal volunteers. Arzneimittel-Forschung, 24, 1653-1657.

Siegel, S. (1956). Nonparametric Statistics for the Behavioral Sciences, pp. 75-83. McGraw-Hill: New York.

Stockbroekx, R. A., Vandenberk, J., Van Heertum, A. H. M. T., van Laer, G. M. L. W., Van $\operatorname{der}$ Aa, M. J. M. C., Van 
Bever, W. F. M., and Janssen, P. A. J. (1973). Synthetic antidiarrheal agents. 2,2-diphenyl-4-(4'-aryl-4'-hydroxypiperidino) butyramides. Journal of Medicinal Chemistry, 16, 782-786.

Van Nueten, J. M., Janssen, P. A. J., and Fontaine, J. (1974). Loperamide ( $R 18553$ ), a novel type of antidiarrheal agent. Part 3. In vitro studies on the peristaltic reflex and other experiments on isolated tissues. Arzneimittel-Forschung, 24, 1641-1645.
Verhaegen, H., De Cree, J., and Schuermans, V. (1974). Loperamide ( 18553 ), a novel type of antidiarrheal agent. Part 7. Clinical investigation. Efficacy and safety of loperamide in patients with severe chronic diarrhea. ArzneimittelForschung, 24, 1657-1660.

Wright, H. K., and Tilson, M. C. (1971). The Short Gut Syndrome; Pathophysiology and Treatment (Current Problems in Surgery), pp. 3-51. Year Book Medical Publishers: Chicago.

\section{The June 1977 Issue}

\section{THE JUNE 1977 ISSUE CONTAINS THE FOLLOWING PAPERS}

Effect of the prostaglandin precursor, arachidonic acid, on histamine stimulated gastric secretion in the conscious dog, and observations on the effect of inhibiting endogenous prostaglandin synthesis M. E. CONOLLY, P. R. BIECK, N. A. PAYNE, B. ADKINS, AND J. A. OATES

Nocturnal metiamide treatment in the management of healed duodenal ulceration M. H. THOMPSON, C. W. VENABLES, P. A. SMITH, AND W. WALKER

Calcium stimulation of gastrin and gastric acid secretion: effect of small doses of calcium carbonate J. BEHAR, M. HITCHINGS, AND R. D. SMYTH

Post-vagotomy insulin test: improved predictability of ulcer recurrence after corrections for height and collection errors N. K. MAYBURY, R. G. FABER, AND M. HOBSLEY

Effect of lysolecithin on gastric mucosal structure and potential difference R. ORCHARD, K. REYNOLDS, B. FOX, R. ANDREWS, R. A. PARKINS, AND A. G. JOHNSON

Gastric emptying in diabetic autonomic neuropathy I. W. CAMPBELl, R. C. HEADING, P. TOTHILl, T. A. S. BUIST, D. J. EWING, AND B. F. CLARKE
Effect of secretin on plasma motilin in man $P$. MITZNEGG, S. R. BLOOM, W. DOMSCHKE, W. H. HAECKI, S. DOMSCHKE, D. BELOHLAVEK, E. WÜNSCH, AND L. DEMLING

Lymphocyte populations in liver biopsy specimens from patients with chronic liver disease J. SANCHEZTAPIAS, H. C. THOMAS, AND S. SHERLOCK

Hepatic damage associated with mineral oil deposits R. W. BLEWITT, K. BRADBURY, M. J. GREENALL, AND HEATHER BURROW

Intestinal perfusion studies in tropical sprue 2. Movement of water and electrolytes M. D. HELLIER, PREMA BHAT, J. ALBERT, AND S. J. BAKER

Jejunal mucosal gamma glutamyl transferase activity in coeliac disease M. J. FAIRMAN, B. B. SCOTT, C. TOOTHILL, AND M. S. LOSOWSKY

Anal pressure studies in spinal patients I. C. WHEATLEY, K. J. HARDY, AND J. DENT

Progress report Oral ulceration and Behçet's syndrome THOMAS LEHNER

Notes and activities

Books

Copies are still available and may be obtained from the PUBLISHING MANAGER, BRITISH MEDICAL ASSOCIATION, TAVISTOCK SQUARE, LONDON, WC1H 9JR, price $£ 2.75$, including postage 